\title{
Research on the Function of Government in the Market Economy
}

\author{
Jinfeng $\mathrm{Xu}{ }^{1}$, Huajuan $\mathrm{Wu}^{2}$ \\ ${ }^{1}$ Nanchang Institute of Science \& Technology, Nanchang, Jiangxi, 330008
}

KEYWORDS: Function Location, Government, Market Economy

\begin{abstract}
At present, China's reform and facing the challenges of economic and social comprehensive restructuring, economic restructuring requires the construction of modern property rights, in this particular background, we need the government's functions and responsibilities repositioning, the need for power of the government to effectively Supervision. Consciously promote government transformation, accelerate the establishment of service-oriented government, our country will have a major impact overall development of reform. Therefore, this article explored the theory government function transformation, based on the government under market economy conditions positioned as a service-oriented government, and how to build a service-oriented government made a number of views, in order to have some reference value in the real world.
\end{abstract}

\section{Introduction}

Government, as part of the national machinery it is with public and mandatory features. Government management is strong backing, and management itself has become the basis for coercive apparatus can sustain. Outranked social managers - country representatives, with a forced mechanism so that others will obey the government the power to make by managers in order to live a certain, this is the real essence of the government administration. The government of this "extra-economic mandatory" feature, mainly derived from the power of the state power, expressed as a governmental authority, the government is relying on state power and institutions play a role. Therefore, the government has what function, if we want to use it to consider that state power and state power became a division of governmental functions and basic function of non-governmental boundaries. On the other hand, the common characteristics are linked to the government also has the function of public administration. With the development of large-scale socialized production, government functions will increasingly simplified, purely administrative bodies will be reduced gradually, job content will gradually simplify. The more society forward, more progress, the government's common features that the more prominent.

\section{The Theory of Government Function Orientation}

Underdeveloped is a basic national conditions of our country, so we still have to take economic construction as the center, but the government can not simply put the primary responsibility on the pursuit of GDP growth, and should be in the "economic construction", but effort "to achieve comprehensive social, healthy and balanced development." In conformity with this, the government should also be positioning function "Economy Oriented Government" to "service-oriented government" changes. The so-called "service-oriented government", depicts the provision of market economy to adapt to the quality of government, from the perspective of government functions, the government should do something, their behavior will be strictly limited in the formulation and 
supervise the implementation of the rules, to create a favorable institutional environment for economic and social development, and provide a stable and secure public goods and services. Proposed the "service-oriented government," the concept is that people under the conditions of market economy the government functions know a qualitative leap, it "from resolving outstanding economic and social contradictions Chinese view, to the transformation of government functions presented a clear target."

\section{The Necessity of Government Function Orientation in Market Economy}

For a long time, there are many problems in our government functional configuration, mainly in three aspects:

From the phenomenon of view, the specific responsibilities of government agencies generally have laws and regulations; however, the terms of reference sources in the government practice is not entirely limited to the specific laws and regulations, and often also by the authorities through the development of regulations or other how the file self-empowerment, or to broaden the mandate by the content vague "three" program. As a result, government agencies in the Parkinson's Law, driven to nothing can not ask anything-point tube, the intervention in economic life, in all aspects of social life, to act as the role of omnipotent government. No wonder the general public to understand the function of government, but internal government departments in different cross-functional, overlapping authority, institutional expansion and so on. However, whether it is in accordance with WTO rules or in accordance with the requirements of the market economy, the government in market economic life must have a clear positioning, not unrestricted involvement and intervention in economic activities, but can not act as competitors enter the market directly, compete with the people in order to avoid market players and the administrative body of identity confusion.

According to the theory of law and economics, and any control activities (including administrative activities of government agencies) are a cost, regulatory agencies their own legitimate interests is an important part of the costs. Deny such benefits or does not give authorities (government agencies) legitimate interests, laws and regulations on the implementation of the lack of basic incentives, government functions is difficult to be fully realized. Due to various factors, our past in the design of government functions, with little consideration to avoid even mention the legitimate interests of government agencies, the government as otherworldly, not self-interest is not self-seeking moral community. According to this logic, of course, can not and need from the system of benefits or government agencies to guard against the possibility of constraints. However, neither the government or is it constitute a personal government, in fact, have the instinct to chase individual interests and needs outside of government functions, ignoring their interests and needs and thus ignored the interests of the necessary restrictions on their system design, will bring the government the exercise of the function of full benefits or reduce color, inevitably leads to a combination of power and unlimited benefits. Practice, people are talking about internal government "the right to compete inch, inch Rapida wins," Foreign "does not work to the benefit to the benefits of work chaos" and other phenomena, the objective function is the government of the benefits or reduce the exercise interpretations best.

The rule of law in the society, "the so-called government, is to bear the mandate from the people, and do about law so that people across the country, no points are equal from top to bottom, can exercise their rights, and the rule of law must be done correctly, incentives and strict impartiality." In this sense speaking, the function of government by the people can only be determined by the constitution, the government functions are required by law to achieve the line. If you obey the law, or the law may be swayed by the will of policy or government officials, then in fact not the rule of 
law, but the rule of man. The difference between the rule of law and rule of man lies not in a country there is no law, but rather how the legal status and role in the country. Specifically, / rule of law is a law as the fundamental basis for government action, law once worked out, government policy can not modify the law to change the law, the head of the government not to change the law to individual commands. When the policy and the executive heads of command and wears conflict, law enforcement agencies should be executed instead of executing the policies and orders. If the law because of the changing situation and showing outdated, unreasonable, it shall recommend that the legislature according to legal procedures to modify or repeal the corresponding laws. Method to modify, repeal before, its effectiveness is higher than the policies and orders. Is based on the rule of man reflects the will of the executive orders and policy as a fundamental basis for government action. Executive may be made on behalf of the law enforcement agencies executed first command, policy, instead of implementing legislation. Like the rule of law does not deny the role of people, like the rule of man does not deny the role of law; but the rule of man is only the law as a tool to rule the people, when the owner that this tool does not hinder hand or easily, it can be abandoned at any time long rule of man society formed to law the concept stage to achieve the government functions great impact.

\section{Government Function Orientation in the Market Economy Needs to Deal with Several Relations}

Traditional administrative law that, in the administrative legal relationship, the legal status of government agencies and citizens are equal, the government is always active, the status of advantages, have the right according to their function as the counterpart to the implementation of the citizens unilateral command and control, while citizens are always in a passive, inferior position, the obligation to obey orders and to accept the regulation. Government and the unequal legal status of citizens on, reflected in the government enjoys the Administrative Priority to Benefit. The so-called administrative priority, refers to the state government to protect the effective discharge of administrative functions, giving priority to their duties on a number of conditions, when the government to fulfill the function of power and rights of individual citizens meet in the same area or the same range, the government has priority exercise and realize the effectiveness of its function. The so-called administrative beneficial rights, refers to a variety of government agencies enjoy material benefits and conditions offered by the State to ensure that they have the ability to exercise administrative functions.

Prerequisite for the formation of the market and it is a citizen (including collective composed of a number of citizens) enjoy equal legal status, independent property and freedom of contract. Market in a broad sense, but also has economic significance form and morphological system, that the modern market economy and market mechanisms. A correct understanding of the relationship between government and market, we must first understand the connotation of the market economy. Market economy has four key elements: First, the market players; Second, market resources; Third, the market rules; Fourth, the market order. Mature market economy requires market players equal rights, freedom of the will (including free market access); configuration of market resources to follow the market requirements of the law; market rules to reflect the coordinated behavior of market players need to reduce the overall total cost of social exchange, the largest limits to facilitate social transactions; market abuse victims are entitled to redress by means of market mechanisms, correct market irregularities, maintaining social credit, restore market order. Development of market economy, the government must respect the market mechanism into full play the role of market economic factors, not pre-empt. 
In general, the government is not a panacea and the market is not a panacea. For areas of the market mechanism can occur effective role of the government should not interfere. In the case of market failure, the government should strive to provide information, improve services, develop market rules reflect market transactions law, to overcome the market blind.

For a long time, the government monopoly to provide all "public goods", become a national natural choice. Justification by government monopoly to supply specific / 0 of public goods are: competition between the police, the army such a professional team as too costly. Despite the existence of such a problem how to effectively control (such as police corruption, military coups) monopoly services, but people usually tend to think that through political institutions and organizations internal financial control and command, can these problems be solved. $1 / 4$ However, from the beginning of the 30s of last century, many countries noted that not all public goods provided directly by the government are required, on the contrary, this "public good" services monopoly, resulting in high cost, avoidance low competition in the market and the emergence of creativity and bureaucracy, so that the "public good" production is always difficult to catch up with the needs of citizens.

For its part, the current deal with the relationship between government and society, the key is to carefully study, a clear definition of the role of government and society respective ranges, where appropriate, through self-regulation to solve social problems, to specific social organization to be responsible. In this regard, with particular attention given to industry associations, intermediary organizations and other social organizations independent of the legal status of government agencies should clarify their rights and responsibilities, not to make them subject to the direct control of the government "two government" disguised continuation of the previous government's function.

\section{Conclusion}

Government is a complex system of organization, governance and socio-economic development and people's daily lives. At present, China is facing a comprehensive economic and social transformation, in this particular context, people increasingly urgent to ask the Government to provide basic and secure public goods and effective public administration, public services for them; increasingly want building an open, transparent and corruption-free government. This requires us to re-orientation of government functions and responsibilities.

\section{Reference:}

[1] Liu Xirui: "service-oriented government - under the background of economic globalization Chinese Government Reform target selection", "medium State administration ", 20027.

[2] Wu Jinglian: "establish a transparent and accountable public service-oriented government", "Finance", June 2003 issue.

[3] Wu first full: "In stepping in to speed up the transformation of government functions and services to build a modern market-oriented government," "Nanjing community Sciences ", in 2003 the first one.

[4] Double Dragon Dynasty, Tian Fang: "Public Service: Government Functions and government reform direction", "Wuhan University" 20026.

[5] "CPC Central Committee on perfecting the socialist market economic system, a number of issues", "People's Daily" October 15, 2003. 